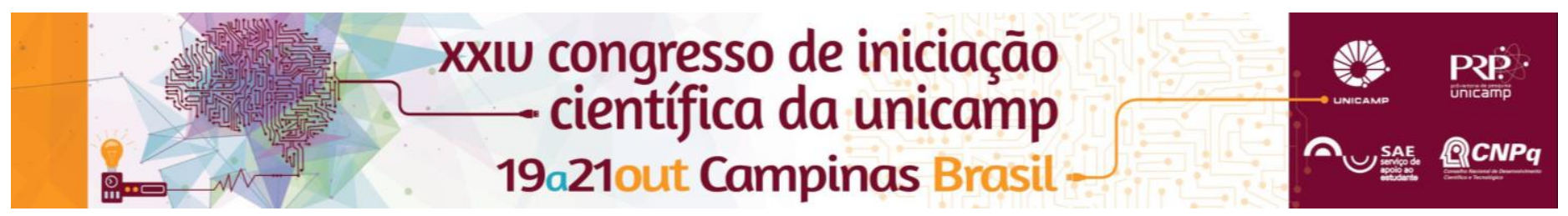

\title{
Padronização de uma metodologia para permitir a diferenciação de reservatórios de fluoreto no biofilme dental
}

\author{
Mateus Xavier de Queiroz*, Diego F. Nobrega, Jaime A. Cury, Livia M. A. Tenuta
}

\begin{abstract}
Resumo
A manutenção de reservatórios de fluoreto $(F)$ no biofilme dental é importante, uma vez que quando liberado para o fluido do biofilme, este íon pode interferir no processo de cárie. Em um estudo in situ prévio, o aumento da retenção de F no biofilme dental pelo tratamento conjunto com cálcio $(\mathrm{Ca})$ foi testado. No entanto, em amostras contendo altas concentrações destes íons, a metodologia de extração disponível não permite a diferenciação dos reservatórios de $F$ retidos no biofilme por ligação à superfície bacteriana (reservatórios biológicos), ou precipitados na forma CaF2 (reservatórios minerais). Neste trabalho, foi avaliada a aplicabilidade de um protocolo de extração diferencial de CaF2 para permitir a extração diferencial desses 2 tipos de reservatórios. CaF2 (10 mg por eppendorf) foi tratado em fluxo contínuo (3,51 mL/h) com soluções subsaturadas: G1: água purificada (sem Ca e F); G2: $1 \mathrm{mM}$ Ca (sem F); G3: $10 \mathrm{mM}$ $\mathrm{Ca}$ (sem F); G4: 1 mM F (sem Ca) e G5: 10 mM F (sem Ca). Após 12 horas de extração, a dissolução do CaF2 nessas soluções foi avaliada, determinando as concentrações de $\mathrm{Ca}$ e $\mathrm{F}$ no seu sobrenadante, por análise colorimétrica $e$ eletrodo íon-especifico, respectivamente. Na dosagem de $F$ foram comparados os grupos extraídos com solução sem $F$ (G1, G2 e G3), e na de Ca, os grupos extraídos com solução sem Ca (G1, G4 e G5). A concentração de $F$ encontrada foi inversamente proporcional à concentração de $C a$ contida na solução de extração $(G 1>G 2>G 3$, para todos os tempos avaliados). Por outro lado, a concentração de $\mathrm{Ca}$ encontrada foi inversamente proporcional à concentração de $\mathrm{F}$ utilizada na extração (G1 >G4 > G5). Os resultados demonstram que é possível extrair CaF2 utlizando soluções subsaturadas contendo um dos íons componentes do sal, porém mais tempo é necessário para dissolvê-lo em soluções com maior concentração de Ca ou F.
\end{abstract}

Palavras-chave: biofilme dental, reservatórios, fluoreto

\section{Introdução}

A manutenção de reservatórios de $\mathrm{F}$ biodisponíveis no biofilme dental é importante, pois estes podem ser liberados para o fluido do biofilme, interferindo com o processo de cárie (Vogel, 2011). No biofilme, o F pode ser encontrado na forma de mineral precipitado $\left(\mathrm{CaF}_{2}\right)$ ou ligado a íons Ca na superfície bacteriana (Rose et al., 1996).

Porém, a metodologia disponível (Vogel et al., 2014) não permite a diferenciação desses dois tipos de reservatórios em amostras contendo alto conteúdo de minerais. Assim, neste trabalho foi iniciado a padronização de uma nova metodologia para esta análise.

\section{Resultados e Discussão}

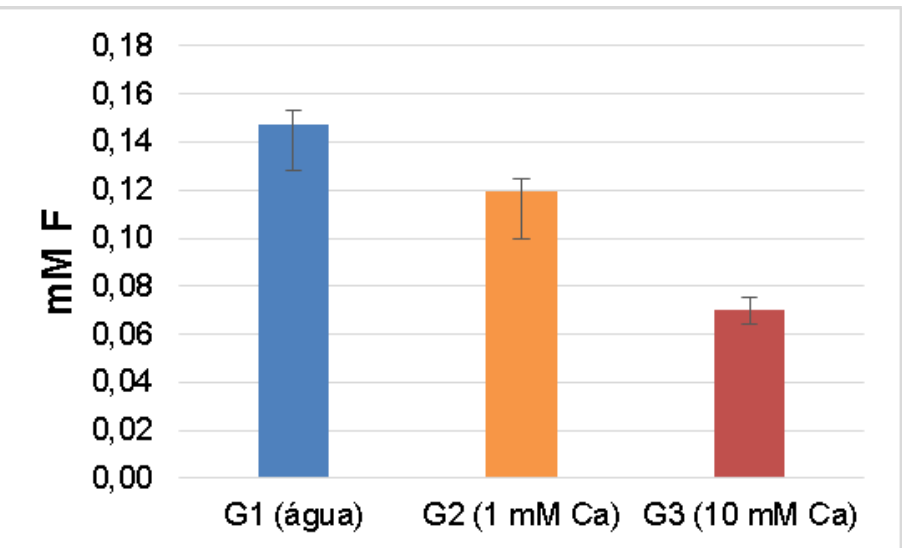

Figura 1. Concentração de $\mathrm{F}$ presente no sobrenadante após $12 \mathrm{~h}$ de extração diferencial (Média $\pm \mathrm{DP}$ ).

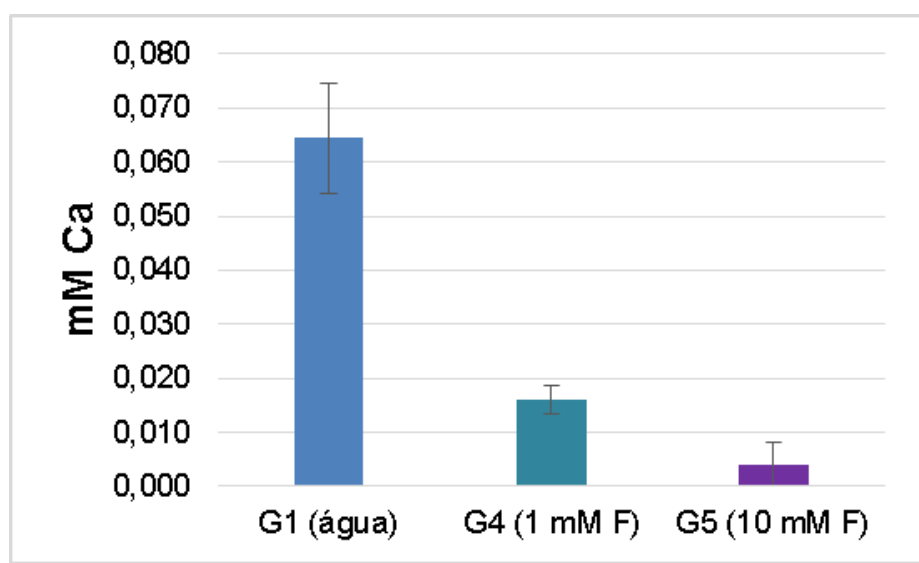

Figura 2. Concentração de Ca presente no sobrenadante após $12 \mathrm{~h}$ de extração diferencial (Média $\pm \mathrm{DP}$ ).

\section{Conclusões}

Os resultados demonstram que é possível extrair $\mathrm{CaF}_{2}$ utlizando soluções subsaturadas contendo um dos íons componentes do sal, porém mais tempo é necessário para dissolvê-lo em soluções com maior concentração de $\mathrm{Ca}$ ou $\mathrm{F}$.

\section{Agradecimentos}

Ao programa PIBIC e CNPq pelas bolsas concedidas ao primeiro e segundo autor, respectivamente.

Rose RK, Shellis RP, Lee AR. The role of cation bridging in microbial fluoride binding. Caries Res 1996;30:458-64.

Vogel, GL. Oral Fluoride Reservoirs and the Prevention of Dental Caries. Monogr Oral Sci, v. 22, p. 146-157, 2011.

Vogel GL, Tenuta LM, Schumacher GE, Chow LC. A calcium prerinse required to form calcium fluoride in plaque from a sodium fluoride rinse. Caries Res; 48(2):174-8, 2014. 